\title{
Shakespeare and the Impact of Editing
}

Gabriel Egan

As readers, almost all of us first encounter Shakespeare in a modern printed edition of his works rather than something resembling the forms in which his first readers encountered him. The conventions of spelling in Shakespeare's time present a barrier that modern editors feel obliged to remove. It is hard enough to understand what Caesar means when he says 'What touches us ourself shall be last served' (Julius Caesar, 3.1.8) without having to read it in the original spelling and punctuation as 'What touches vs our felfe, shall be last feru' $\mathrm{d}^{\prime} .{ }^{1}$ The old-fashioned long $s$, the appearance of $u$ where we would expect $v$ and vice versa, the abbreviation of preterite verb endings (' $d$ ), and the use of punctuation to show pauses for breathing rather than to mark off grammatical clauses - if indeed that is why a comma here obtrudes between a verb and its subject - convey nothing we really need to know. These features merely distance Shakespeare's writing from modern readers.

A great part of the labour of modern editors, and indeed the one thing that they almost all agree they should be doing, is modernising the letter-forms, spelling and punctuation of Shakespeare's works. When asked by non-specialists just what editors of Shakespeare do, these activities come readily to mind as benefactions likely to be granted approval by all but those purists who delight in alienation from the author. But once we get beyond these merely superficial activities, the need for editors of Shakespeare becomes rather more difficult to explain. To appreciate the impact of their work - to understand why one modern edition of a play may be quite unlike another - we must return to the origins of Shakespeare's writing and consider how it has come down to us. Modern editions based on the same raw materials - Shakespeare's work - are constructed by differing principles and offer distinctly different texts once we look beyond the superficial similarities. 
The first readers of his plays would have been Shakespeare's fellow actors in the playing company called the Lord Chamberlain's Men (renamed the King's Men in 1603) in which Shakespeare spent almost his entire professional career. To this company of actors Shakespeare would have passed one or more copies of the script as he completed each play he wrote for them. Necessarily, such a script would have been handwritten in ink on paper, taking the material form of a 'manuscript', from the Latin words manus for 'hand' and scriptus for 'written'. With the exception of a small part of one play to which Shakespeare contributed a scene-and-a-bit some time in 1600-3, called Sir Thomas More, none of these manuscripts in Shakespeare's handwriting survives. But we can get an idea of what they probably looked like by considering the few remaining authorial manuscripts of other playwrights and by considering Shakespeare's likely working practices.

Things that we consider important to convey to a modern reader might well have been omitted by Shakespeare when writing for his fellow actors, and certainly were omitted by other professional dramatists. For example, certain kinds of stage business implied by dialogue ('I'll stop your mouth' or 'Here is my purse') are generally not supported by stage directions. One reason for such omissions is that in most cases the dramatists could attend rehearsals and other pre-performance discussions to simply tell the actors what they had in mind. Just as importantly, some things probably did not need saying at all. Being among his fellow professional actors, Shakespeare quite likely felt that certain decisions were rightly their prerogatives as performers, not his as the writer, and other details were most likely covered by the routine practices of theatre. A special case of omitted detail in playscripts from this period is that when a single actor is to 'Enter' it is not usually specified which door he (actors were always male) should use. But where two actors must enter using different doors this is often recorded, as with 'Enter a Fairy at one door and Robin Goodfellow, a puck, at another' (A Midsummer Night's Dream, 1.2.0). These characters are to be imagined coming from different directions and meeting in the forest outside Athens, so entering through different doors is somewhat more realistic than entering through the same one, although modern notions of realism are no sure guide when making sense of a script that refers to a pair of doors in a forest.

Exits are more tricky, since surviving scripts from the period frequently omit these entirely, leaving the actor to figure out when he is no longer needed on stage and should leave. This seems a striking omission from our modern point of view, but begins to make sense when we start to think of the purposes for which playscripts were created 
in Shakespeare's time. If a script were constructed for the purpose of managing the backstage activities of a performance-in-progress then the omission of 'Exit' is understandable, since 'Enter' marks when the actor should be sent out onto the stage, but after that he is on his own: no one backstage can bring him off again. Considered in the light of the practicalities of the theatre in Shakespeare's time, the omission of a great many things that we would like to find explicitly addressed is unsurprising because the agreed customs and practices of the theatre rendered it superfluous to record them. One of the areas of expertise required of the modern editor, then, is knowledge of early modern theatrical practices from which to make reasonable guesses about what words to invent for a modern edition, and where to put them, in order to cover details omitted in the original documents.

\section{Texts in motion}

It is possible that the script Shakespeare gave his actors went through various transformations before the play was first performed. The only means of making extra copies of a script was to have someone write it out by hand (the process called transcription), and since paper and a scribe's time were expensive it was not possible to give each actor a full copy of the script made this way. Instead, each actor received only the lines he was to speak, preceded by a few 'cue' words, the last ones spoken by the previous speaker. ${ }^{2}$ These 'parts', as they were called, collectively formed a copy of the whole script, but it would not be a linear reading text that we would recognise. It is possible that another complete transcript of the author's papers was made in order to provide a reading copy for the state censor, the Master of the Revels, who had to grant a performance licence before the play could be acted in public. For all we know, other complete transcripts might have been made for other necessary purposes, such as the provision of properties and the casting of the play, or, later, to give an important aristocratic patron a clean reading copy.

A great deal of the debate amongst twentieth-century editors of Shakespeare was focused on determining how many copies of the author's original papers might have been created as part of the routine procedures for getting a new play into performance, and what kinds of information might have been contained in each one. Since none of these manuscript documents survive in Shakespeare's case, why would this even matter? Why would editors waste time debating what might have appeared in documents that no longer exist and might not, in 
some cases, ever have existed at all? The answer is that what do survive are the first printed editions of Shakespeare, and by definition each of these was made by the typesetters using as their 'copy' - that is, the authoritative document whose words they were setting in type one or more of these preceding (now lost) manuscripts. Since all we have are these early printed editions, they give us our only access to what Shakespeare wrote and it is to those that editors must turn to make a modern edition of Shakespeare.

Why then - as a purist might enquire - do we bother making modern editions at all, rather than just reading the earliest printed editions? What are editors for, again, besides modernising the spelling and inventing missing stage directions? The answer to this question takes us back to those now-lost and perhaps in some cases only hypothetical manuscripts on which the first printed editions were based. When we examine the early printings, they contain puzzling flaws that seem only explicable in terms of those manuscripts. Sometimes the flaws are simple printing errors (typos) that are easily detected and fixed. But others are particular words (or 'readings' in the editors' parlance) that we suspect may be corrupted but which might on the other hand be quite correct and merely strange to us. Sometimes we find in the early editions features that are not quite errors exactly, but which do not conform to modern expectations of readability in a playscript. How editors respond to these puzzling cases varies considerably between modern editions.

Take, for example, the edition of Romeo and Juliet printed in 1599, in which Juliet's mother has speech prefixes that call her 'Wife', 'Old La[dy]' and 'Mo[ther]' depending on who she is talking to. ${ }^{3}$ Once R. B. McKerrow pointed it out, the explanation for this seemed blindingly obvious: Shakespeare thought of the character not in fixed but in relational terms, so his own label for her varied as she fulfilled these different social roles at different moments in the play. ${ }^{4}$ This early edition, it seemed, was printed from Shakespeare's own manuscript in which such name variation would naturally be present, and other early editions in which the speech prefixes are more consistent might reflect a process of tidying up of the script during rehearsal and other preparations for first performance.

If one believed that the play manuscripts that they received from dramatists were seldom recopied by theatre companies - because scribes' time and paper were expensive and the proliferation of copies of a valuable property was not generally desirable - then one might well suppose that the 1599 edition of Romeo and Juliet reflects the variations in speech prefixes for Juliet's mother because its printer held 
Shakespeare's own handwritten manuscript as his guide while he set the type. If that were true, this 1599 edition brings us as close as we can get to - just one remove from - Shakespeare's lost manuscript of the play. Romeo and Juliet was printed again in 1609 , but the new edition seems to have been based on the 1599 edition rather than on Shakespeare's manuscript, and when the play was printed in the 1623 Folio it seems that the 1609 edition, itself a reprint of the 1599 edition, was used for the typesetting. Whenever a book is simply reprinted the inevitable printing errors-begin to accumulate. Believing all the hypotheses that I have just sketched, many twentieth-century editors argued that the 1599 edition of Romeo and Juliet was indeed printed directly from Shakespeare's own manuscript and hence should be the basis of any modern edition in preference to an earlier edition published in 1597 and any later edition, including the 1623 Folio.

For most of the twentieth century editors thrashed out these principles of textual authenticity and understood as their first obligation the laborious task of figuring out just which early edition of Shakespeare was a reprint of which other preceding edition, which were based on authorial manuscripts, and which on other kinds of manuscript. ${ }^{5}$ With this knowledge, an editor could find the early edition that stands at the root of the genealogical tree of textual transmission that began with the author's first complete manuscript and could base the modern edition on that. Indeed, this process (called recension) of arranging the editions into a family tree came to be considered the essential groundwork for any serious (that is, 'critical') edition of a play, such as the second series of the Arden Shakespeare that appeared between 1951 and 1982.

Once recension had established which early printed editions were merely reprints of other existing printed editions, the remaining editions that were not reprints must, by definition, have been set from manuscripts. According to standard twentieth-century editorial theory, known as New Bibliography, the next task was to determine in each case whether the manuscript was the author's own papers or merely a transcript of these (or a transcript of a transcript) used for such purposes as managing a performance of the play as it happened. The latter kinds of manuscript would be distanced from Shakespeare's own writing by all manner of secondary interference: the adding of sound and property cues, the tidying up of speech prefixes and stage directions, and (most damagingly) the alteration or even excision of lines resulting from decisions made in rehearsal. Philip Edwards summed up the idea in his edition of Hamlet: 'it is sadly true that the nearer we get to the stage, the further we are getting from Shakespeare'. ${ }^{6}$ 
Just as Edwards was making this remark, a team of editors was putting the finishing touches to an edition of Shakespeare for Oxford University Press that took entirely the opposite approach. ${ }^{7}$ Rather than seeing the theatre as a place where Shakespeare's plays were damaged by others' interference, they saw the work of these many hands as a collaborative endeavour that fulfilled the potential that was only latent in Shakespeare's original script. Shakespeare, they argued, was fully engaged in the work of his theatre company, sharing in its risks and profits, and would have seen the processes of readying a play for performance, including rehearsal, as opportunities for collective refinement of the script, not a debasing of it.

Where it appeared that an early edition of one of his plays reflected changes made in the readying of the play for performance, the Oxford Complete Works editors preferred to show their readers how the play looked after such changes rather than before them. This extended even to cases where whole speeches were apparently cut in rehearsal, so that their edition of Hamlet excluded from the main body of the play the soliloquy beginning 'How all occasions do inform against me' - present in the edition of 1604-05 but not the 1623 Folio - and put it into an appendix that they print after the end of the play to hold speeches cut during rehearsal.

Many reviewers of the Oxford Complete Works thought that in doing this the editors had gone too far, and had exercised too much editorial power by relegating well-loved speeches to an appendix. But when one considers the principles on which these decisions were made, they cannot logically be faulted. If one thinks that Shakespeare's plays achieve their apotheosis in performance then the state of the script for the first performances - ones that Shakespeare himself could most readily influence and probably oversaw - are especially important moments in the life of the ever-evolving text and something quite reasonable for the editors to try to reflect in their modern editions. These first performances are not the only possible moments in the life of the play that one might choose to base a modern edition upon, and other kinds of modern edition that privilege the version of the play as it left the author's pen - before entering the collaborative phase of readying and rehearsal - are equally defensible. But privileging the author's pre-social script over the socialised version arising from collective preparation would be incompatible with the conviction that Shakespeare was primarily a man of the theatre for whom the first complete draft of a play was only the beginning of its fullest realisation in performance. 
Since the Oxford Complete Works edition appeared in 1986, four major shifts in editorial thinking have changed how we go about making a modern edition. The first is the collapse of the consensus sketched above about the ways that we determine for each early printed edition the question of whether its underlying copy was an authorial manuscript or one reflecting subsequent readying for performance. This consensus was fundamental to the New Bibliography, and in the 1980s and 1990s it was subject to a series of criticisms arising from its overly specific characterisation of the differences between authorial papers and those used to run a play in performance. ${ }^{8}$ More generally, the editorial confidence that led New Bibliographers to interfere extensively in the texts they were editing, especially in correcting what they perceived as errors, has come to be seen as editorial hubris.

The second change is that, partly as a consequence of the Oxford Shakespeare editors pressing this point, it has become generally accepted that as well as accommodating others' changes to his plays Shakespeare revised them himself so that differences between early editions might simply reflect authorial second thoughts. The third major change in the past 30 years is that much has been learnt about Shakespeare's habits of collaborative writing, and we now know that perhaps a third of all his plays were co-authored. ${ }^{9}$ The fourth major change is that our image of Shakespeare as essentially a man of the theatre who took little or no interest in how his plays reached a print readership has been challenged, and many commentators now accept that he also sought and achieved success as a published writer, as is discussed by Siobhan Keenan in Chapter $2 .{ }^{10}$ Some of what we find in the early editions may never have been intended to be performed in the theatre at all and was written by Shakespeare with his readers, not his audiences, in mind. This theory has the considerable merit of helping to explain why Shakespeare wrote plays that are considerably longer than most other plays of his time. ${ }^{11}$

\section{Present problems in editing}

Let us take these developments in reverse order. The new idea that Shakespeare wanted to be, and succeeded in becoming, a published author has not yet had a substantial impact on what editors do, but it surely must. Editing As You Like It for the third Arden Shakespeare series, Juliet Dusinberre declared herself convinced by this new idea about Shakespeare and so paid more attention to its literary qualities than previous recent editors did. ${ }^{12}$ But because As You Like It survives only in 
the 1623 Folio edition, Dusinberre could not exercise her conviction by choosing a more readerly over a more theatrical early edition to base hers upon.

Our new knowledge about Shakespeare's habits of collaborative writing present a series of special problems for editors. We can no longer assume that we even know the boundaries of the Shakespeare canon that we are trying to edit. New admissions to the recently expanded canon are Edward III (co-written with a person or persons unknown), Sir Thomas More (with Anthony Munday, Henry Chettle, Thomas Dekker, Thomas Heywood and one other person unknown), Arden of Faversham (with a person or persons unknown) and The Spanish Tragedy (added to by Shakespeare after Thomas Kyd's death). ${ }^{13}$ At the same time as expanding in these directions, the canon is contracting in other directions as we ascribe to other writers parts of plays we thought wholly Shakespeare's because they appear in the 1623 Folio. This affects Henry VI Parts I, II, and III (co-written with Christopher Marlowe and others), Titus Andronicus (with George Peele), Timon of Athens (with Thomas Middleton), Henry VIII (with John Fletcher), and Measure for Measure and Macbeth (now known to be adaptations of lost Shakespearean originals made by Middleton after Shakespeare's death); see again footnote 9 for the references to the vast body of scholarship supporting these attributions. Pericles (with George Wilkins) and The Two Noble Kinsmen (with John Fletcher) have long been acknowledged as collaborations.

The reshaping of the Shakespeare canon has practical implications for an editor working on problematic moments in a single play. When deciding whether a certain word or phrase is an error or a Shakespeareanism, it is usual to look for parallels and analogues in other Shakespeare plays. No longer can this be done on the assumption that every play in the 1623 Folio provides evidence for Shakespeare's habits of writing: one must look to only those parts of the collaborative plays that are his, and must look beyond the 1623 Folio at his contributions to other plays. More complicatedly still, when editing plays that are now known to be Shakespeare's collaborations there can no longer be assumed (if ever there could) a singular authorial intention, as Suzanne Gossett has pointed out. ${ }^{14}$ An editor must ask whether each author confined his intention to the part he wrote, or hoped to influence the other's work. This raises the awkward question of whether an editor should treat the entire play as if it were an homogenous artistic unity by effacing any discontinuities arising from co-authorship, or should instead highlight these discontinuities to make plain the composite nature of the play. 
The now-general acceptance that Shakespeare revised his plays presents a special problem for the printed edition because it is inherently singular, although some attempts have been made to represent how a play looked 'before' and 'after' alteration. The Oxford Collected Middleton included Shakespeare's Macbeth and Measure for Measure because we now know that the 1623 Folio texts of those plays (our only authorities for them) reflect the effects of adaptation by Middleton. Both plays were presented as 'Genetic Texts' in the collection, meaning that the editors attempted to convey as far as possible their genesis towards their final state in the 1623 Folio. ${ }^{15}$ The primary means for this was typographical: lines added or rewritten by Middleton were presented in boldface type, lines deleted by Middleton (or meant to be deleted) were printed in grey, and lines moved by Middleton appeared in grey where they originally stood and in boldface where they ended up. Thus to apprehend Shakespeare's original version one should read the regular type and the grey and to apprehend Middleton's version one should read the regular type and the boldface. This innovation has not become a widespread solution to the problem of conveying how texts change over time and would be unsuitable for less well-known plays. That is, this kind of disorienting innovation is suitable only where it does not distract from the important editorial duty of conveying unfamiliar works to new readers. What Gary Taylor wrote of Macbeth in this regard applies equally to Measure for Measure: the plays are 'already available in more editions than any other work in this Collected Works; readers who want a more comfortable text can find it easily enough elsewhere' ${ }^{16}$

The first of the four substantial changes in editorial thinking since the 1980s, the collapse of the consensus known as the New Bibliography, has had the most profound impact on editors' behaviour because it has reduced confidence in their own ability to spot and correct errors. Most editors no longer think that they can tell from an early printed edition what kind of manuscript - authorial or theatrical - it was based upon. Without this foundational knowledge, they feel unable to explain the differences between early printed editions because there exist more possible causes than there are effects to be accounted for, and the competing causes overlap in their consequences. That is to say, authorial revision can easily produce effects that are difficult to tell apart from non-authorial revision. (In the case of Macbeth and Measure for Measure the editors were fortuitously enabled to make this distinction by the 1623 Folio texts containing material, including a popular song and topical references, that was most likely composed after Shakespeare's death, eliminating him as the creator.) Textual corruption in scribal copying 
and in the printshop can easily produce effects that are difficult to tell apart from non-authorial revision. For example, the letter $u$ or $n$ may be accidentally inverted in the printing press to produce a false but poetically meaningful variant that is not obviously an error: in Shakespeare an unhappy woman may be both louely (= lovely) and lonely.

The term 'over-determination' from psychology has come to be used generally where there are more possible causes than are needed to explain any particular effect and where several of them may be operating at once. Over-determination is a significant philosophical obstacle to editorial work. Since texts are almost always to some degree corrupted in transcription and printing, we can be sure that differences between the various early printed editions of Shakespeare are in part due to such corruption. But with authorial and non-authorial revision also highly likely to be present it becomes difficult to decide the cause of particular variants. Once editors stop believing that they can distinguish the signs of authorial papers from those of post-rehearsal papers their ability to make such distinctions is significantly weakened.

If one is sure that a particular early edition was based solely on authorial papers, then by definition one can exclude non-authorial revision as the cause for a particular puzzling feature: it must be a Shakespeareanism or else a corruption in transmission. Equally, if one is sure that a particular early edition was based on papers that had been annotated by someone in the theatre to show sound cues (such as a flourish of trumpets for each royal entrance) and a full set of stage directions, then one can explain the apparent misplacing of such features as merely errors made during annotation and not authorial peculiarities to be understood and explained. Without such guiding principles, editors are apt to give up on using the early printed editions in an attempt to reconstruct the play as it was first written or as it was first performed, and instead they aim for the less ambitious target of simply reproducing a particular early edition, cured of its obvious textual corruptions. This intellectually modest practice of 'single text' editing, aiming to reproduce not the artistic work as an ideal but only its instantiation in a particular early edition, is now what most editors do. Its danger is that in removing only the obvious textual corruptions they leave behind the merely likely corruptions that previous, more confident editors, cleared away.

\section{The impact of three major editions}

To illustrate how the above changes in the theoretical underpinnings of editions of Shakespeare have played out in practice over the past three 
decades, let us take three illustrative cases: the first edition of The Norton Shakespeare published in 1997 (based on the Oxford edition of 1986) and edited by Stephen Greenblatt and others, the Royal Shakespeare Company (RSC) Complete Works published in 2007 and edited by Jonathan Bate and Eric Rasmussen, and the third edition of The Norton Shakespeare published in 2015 and edited by Greenblatt and others.

\section{The Norton Shakespeare first edition (1997)}

After decades of false starts, progress on the Oxford Complete Works that eventually appeared in 1986 began in earnest in 1978 and its editors were full-time employees of the press rather than being academics making time for the work between other obligations. ${ }^{17}$ This ability to focus solely on the task enabled them to undertake the most thorough survey of the textual foundations of Shakespeare ever attempted, and the edition's Textual Companion remains the single most useful resource on this topic. ${ }^{18}$ Although it was originally intended to have explanatory notes, the Oxford Complete Works appeared without them, making it unattractive to the large American undergraduate student market. ${ }^{19}$ (In American universities, unlike British ones, it is common for students not studying English Literature as their main topic to nonetheless take at least one course in it, and these courses often feature Shakespeare's works.) Via a deal with Oxford University Press, the American publisher W. W. Norton released in 1997 a Complete Works of Shakespeare 'based on' the 1986 Oxford Complete Works. What does 'based on' mean? The general editor Greenblatt characterised his team's job as 'to prepare the necessary teaching materials around the existing Oxford text' in order to make it suitable for classroom use. ${ }^{20}$ The Norton editors were able to use the unpublished commentaries of the Oxford Complete Works and supplied many more materials to help the undergraduate student make sense of Shakespeare, including genealogies of historical figures, explanations of how early modern theatres operated and transcriptions of key historical documents. Regarding the most radical innovations of the Oxford Complete Works, Greenblatt listed a series of Norton differences that can fairly be characterised as a combination of some advances and much backsliding. ${ }^{21}$

The Oxford Complete Works offered two fully edited texts of King Lear: one reflecting the play as originally composed in 1605 and represented in the 1608 edition and one reflecting the script after Shakespeare's extensive revision of it in 1610 and represented in the 1623 Folio. 
Where the Oxford printed these two scripts in different parts of its chronologically ordered edition, the Norton - which was also chronologically ordered for everything else - printed them on the facing pages of each opening in succession. This has the advantage of showing most clearly where one version has something that the other lacks, made visible by as much as half a page being blank. At one point there is an entire blank page-and-a-half for where the 1623 Folio lacks the scene (17) in which Kent receives news of Cordelia and the King of France from the First Gentleman.

The facing-page format also allowed ready comparison of lines that are variant between the two versions, such as Regan's 'Sir, I am made/ Of the self-same mettle that my sister is' (1608 edition, 1.60-61) and 'I am made of that self mettle as my sister' (1623 Folio, 1.1.67). To see how well this facing-page solution presented the phenomenon of minor textual variation, compare it with the Arden 3 edition of the play published the same year, in which R. A. Foakes elected to use superscripted ' $Q$. . . Q' (for 'quarto', the book format) and 'F . . . F' (for 'Folio') to show words appearing only in one or other edition: "QSir $\mathrm{I}$ am made of that self mettle as my sister' ${ }^{22}$ To avoid littering the line with too many markers, Foakes treated whole phrases - selfe same versus self- and sister is versus sister - not as alternatives but as equivalents for which he could prefer the 1623 Folio wording without marking it. Thus readers of the Arden 3 King Lear might easily gain the impression that the 1608 and 1623 editions differ only regarding the first word in this line, while the Norton fully disclosed the variation.

The Norton edition's admirably clear use of facing pages to help readers apprehend the complex textual variations between the two early editions of King Lear was followed by something of a collapse in confidence: a third, conflated text that tried to combine the 1608 and 1623 editions. This is necessarily an intellectually compromised solution to the problem that readers want one version, not two, of a play and yet do not want to miss anything that Shakespeare wrote. The trouble, of course, is that something being present in the first version and absent in the second might well be compensated for by something else absent in the first version and present in the second. That is, a revising author might cut here and add there to execute a single artistic change. In conflating the two versions we end up with duplication, offering both of two pieces of material that the author never intended should appear together because they were meant to be alternative, not complementary, ways to handle a dramatic point. 
Stanley Wells understood the pressure to give readers what they want in this regard, but was memorably picturesque in conveying the artistic incoherence of acceding to it:

It is perhaps understandable that they [editors] should therefore base a text on the one that they regard as closest to Shakespeare's final version while adding to it bits that are present only in the other version. It is, I say, understandable, even though its effect might resemble that which would be achieved by an art expert faced with two versions of a portrait who decided that the best way to represent them would be by superimposing one upon the other, even if in the process he made the sitter appear to possess four eyes. ${ }^{23}$

The problem is not quite so great for other plays as for King Lear - the one for which we have the clearest evidence of substantial authorial revision - but it does also affect Hamlet, which appeared in an edition of 1604-05 that seems to reflect the play as first written and before refinement in preparation for performance, and appeared in the edition of 1623 that seems to reflect the play after such refinement. Mostly this refinement consisted of the cutting of various speeches, which the Oxford Complete Works, based on the 1623 edition, published as a series of 16 Additional Passages - present in the 1604-05 edition, absent in the 1623 edition - that they printed at the end of the play. The Norton Shakespeare put these Additional Passages back into the main body of the play but, aware of the logical incoherence of conflation, they indented them and rendered them in a different typeface to make apparent their different provenance. As Greenblatt remarked, readers wanting to read the 1623 version 'can simply skip over the indented ... passages' ${ }^{24}$ This typographic innovation was meant to serve the same function as the more sophisticated use of three weights of typeface (normal, grey, bold) in the Oxford Collected Middleton, as we have seen. The same expedient was used to a lesser extent in The Norton Shakespeare for other plays where conflation is undesirable.

This typographic expedient is only a partial solution to the problem. As Paul Werstine pointed out, ${ }^{25}$ there are in the $1604-05$ and 1623 editions of Hamlet two distinctly different explanations for why, before their duel in the final scene, Hamlet apologises to Laertes about his behaviour at Ophelia's graveside. In the 1604-05 edition but not the 1623 edition - and thus reproduced in the Norton indented and in a distinct typeface - there is a passage in which an anonymous lord tells Hamlet that 'The Queen desires you to use some gentle entertainment 
to Laertes before you fall to play'. ${ }^{26}$ In the 1623 edition but not the 1604-05 edition, Hamlet says to Laertes 'I am very sorry ... That to Laertes I forgot myself;/For by the image of my cause I see/The portraiture of his' ${ }^{27}$ These are competing, alternative exclusive explanations for Hamlet's apology: in revision (most likely by Shakespeare), one explanation replaced the other. Although the typography of The Norton Shakespeare indicates which lines are unique to the 1604-05 edition - by indenting and styling them - it has no means for showing what is unique to the 1623 edition, so the reader cannot readily see that the 1623 explanation for Hamlet's behaviour is an alternative to the 1604-05 explanation. Indeed, the reader of the Norton who dutifully digests rather than skipping over the passages that are indented and styled hears both explanations and will quite possibly assume that Shakespeare wanted Hamlet to have two reasons to apologise when in fact Shakespeare wanted only one and changed his mind about what it should be. It is hard to see how misleading the reader in this way can be justified as arising from the needs of students and their teachers.

As we shall see, when Shakespeare first wrote Henry IV, Part I the fat knight Sir John was originally surnamed Oldcastle (rather than Falstaff), and for this play the Oxford Complete Works used this name and the original names of his companions Russell and Harvey. In deference to the needs of teachers and 'the centuries of enthusiastic criticism' of the play, the Norton edition changed these names to the more familiar (but historically belated) Falstaff, Bardolph and Peto. ${ }^{28}$ It is not at all clear that pedagogical expediency requires readers to be given not the character names that Shakespeare originally chose but instead the alternative names that he was forced to invent because powerful persons at court objected to the original names as insulting to their own ancestors. This is nothing but censorship, and we should teach students to resist and undo such abuses of power rather than accepting them as inevitable artistic compromises.

One aspect of the Oxford Complete Works that its editors soon came to see as a mistake was the use of broken brackets to indicate their 'debateable editorial intervention' in stage directions. That is, the Oxford editors freely rewrote Shakespeare's stage directions where they thought that their changes were essential to the action of the play or the reader's comprehension of it, providing necessary exits where the early editions lack them, correcting errors in names, and so on. But where such interventions were not certain - say, giving a character a property to hold because she refers to it, or indicating that a speech is spoken to be heard only by certain other characters - the Oxford editors placed the words they added inside broken brackets. 
The trouble is, of course, in distinguishing between certain and debatable interventions, and the Oxford editors came to believe that they should have emended stage directions without making any such distinction since 'Our edition, like all others, is thoroughly mediated, and it is both useless and dishonest to pretend otherwise' ${ }^{29}$ The brackets give the false impression that words outside of brackets were from Shakespeare's own stage directions, but in fact here too editors had altered the wording, but left no signs of it because they were certain of the need for those changes. Better to have no brackets and tell the reader that stage directions had been emended where necessary, just as the dialogue had been. The Norton edition moved in the opposite direction, deciding that wherever its stage directions used words that cannot be found the 1623 Folio or one of the preceding editions, these should be placed in square brackets. ${ }^{30}$ This approach suggests a greater respect for - perhaps undue deference to - the authority of the early editions than the editors of the Oxford Complete Works showed in their radical rethinking of the bases for modern editions.

\section{The Royal Shakespeare Company (RSC) Complete Works (2007)}

For 16 of the 36 plays in the 1623 Folio of Shakespeare, that edition was not the first: there exist earlier single-play editions, usually more than one for each play. (Of these, Henry IV, Part I was the most popular in print, reaching seven editions by 1622 ; the average across all 16 plays was 2.75 editions before the Folio.) For a further four plays in the 1623 Folio there had been earlier publication of a play somewhat similar in title and/or plot and/or language: before The Taming of the Shrew there had been The Taming of a Shrew (1594), before King John there had been the two-part Troublesome Reign of King John (1591), before Henry VI, Part II there had been The Contention of York and Lancaster (1594), and before Henry VI, Part III there had been The True Tragedy of Richard Duke of York (1595). For these four plays, the relationship between the 1623 Folio text and the earlier edition is uncertain, and scholars have long debated whether some might be early versions of the same plays, or sources for the same plays, or perhaps - although this explanation is largely out of favour now - the early editions might be more-or-less pirated texts put together by minor actors collectively recalling and writing down the lines that they spoke in order to cobble together a saleable manuscript for a publisher.

Thus for 20 plays, more than half of those in the 1623 Folio, there exists a preceding edition that an editor would want to consider as perhaps an alternate witness to what Shakespeare wrote. When this 
consideration was first systematically undertaken in the nineteenth and twentieth centuries, it was found that in most cases the 1623 Folio text was essentially a reprint of one of the existing editions. ${ }^{31}$ For just five of the plays for which an earlier edition existed - The Merry Wives of Windsor, Henry IV, Part II, Henry V, Hamlet and Othello - did the 1623 Folio publishers eschew reprinting that earlier edition and instead freshly set their text from a manuscript. ${ }^{32}$ For the rest, a copy of an existing print edition was reprinted in the 1623 Folio, but only after it was first annotated by comparison with an authoritative manuscript supplied by the acting company.

This process of annotation was sometimes thorough (making the 1623 Folio text markedly different from the earlier edition on which it was based) and sometimes careless (leaving the 1623 Folio text much the same as the earlier edition on which it was based). Because the manuscripts used for this process of annotation appear to be authoritative coming from the theatrical company and thus being independent witnesses of how Shakespeare's plays were first performed - the resulting 1623 Folio texts have a kind of mixed authority. Because the 1623 Folio texts of such plays are primarily reprints of existing earlier editions an editor ought to prefer that earlier edition as the basis for a modern one (since inevitable corruptions in transmission mean that originals are always to be preferred over copies) but, having what John Jowett and Gary Taylor memorably and aptly called 'sprinklings of authority', each of the 1623 Folio text's individual differences from the edition it reprints (differences created by the process of annotation) commands special attention as possibly a correct reading derived from the authoritative manuscript and not present in that earlier edition. ${ }^{33}$ This gives editors of some plays a lot of difficult work to do.

One might expect that a specially commissioned Complete Works edition by the Royal Shakespeare Company that on its half-title declared itself to be 'based on the 1623 First Folio' would be the place for this painstaking editorial work to find its fullest expression. Careful readers' alarm bells sounded, however, when the half-title described the 1623 Folio as 'the first and original Complete Works' of Shakespeare, when of course it was at best a complete plays edition - strictly speaking a collected plays edition, since some plays were missing - and not a complete works at all: Shakespeare's extensive output of non-dramatic poetry is absent from the 1623 Folio.

In fact, the half-title's claim that the RSC Complete Works was 'based on' the 1623 Folio meant simply 'reprinted from': for each play the edition merely modernised the spelling and punctuation of the 1623 
Folio, corrected its most obvious printing errors, and provided the kinds of regularised apparatus that modern readers expect. An example of the last of these features is that where the 1623 Folio text of Romeo and Juliet retains the earlier editions' variability in the speech prefixes for Juliet's mother - calling her 'Wife' and 'Old La[dy]' and 'Mo[ther]'- the RSC edition regularised the name as 'LADY CAPULET' ${ }^{34}$ (Just why the editors gave her the title 'LADY' is unclear: then as now, to describe someone as an old lady is not to imply that she has an aristocratic title, and nothing in the play suggests this about the Capulets.) The irregularity of the 1623 Folio is thus smoothed for the modern reader, but it remains the sole authority for the dialogue of each play.

For the plays first printed in the 1623 Folio this editorial principle is entirely just and has no ill effects. But for plays for which there exists an earlier edition, the RSC Complete Works's preference for the 1623 Folio in every case is merely dogma: we have no reason to assume that the 1623 Folio will in each case take us closest to what Shakespeare wrote. And in a few particular cases, we can be certain that the 1623 Folio takes us further from what Shakespeare wrote than would be case if we read the preceding edition. Two examples of this may stand for several. Shakespeare's Richard II was first printed in 1597 and reprinted (each time from the previous edition) in 1598 (twice), 1608 and 1615. The 1623 Folio text was for the most part printed from a copy of one of the 1598 editions that was first annotated by reference to an authoritative manuscript from the playing company. ${ }^{35}$ At the play's climax, Sir Piers Exton presents Henry IV with the body of his predecessor King Richard II, hoping for royal approval of, and reward for, the murder. In the 1597 edition, Henry IV's response is:

king Exton, I thanke thee not, for thou has wrought

A deed of slaunder with thy fatall hand,

Vpon my head and all this famous Land. ${ }^{36}$

This accusation of slander is no small point, since the play makes much of the role of poor public relations in Richard's downfall. The new king's first concerns are to shore up the reputation of the monarchy that he weakened as an institution by overthrowing his cousin Richard. Henry is himself in considerable danger of being overthrown in turn and needs to stop the social turmoil he has set in motion, as the next two plays in the cycle will illustrate. In the closing moments of Richard II, Henry forgives his implacable enemy, the Bishop of Carlisle, who spoke eloquently against the sin of overthrowing an appointed monarch. The shoe, we might say, is now on the other foot. 
Leaving the deposed Richard in prison for the rest of his life was much the safest policy, and by murdering him Exton has brought upon Henry the same public relations disaster - an accusation of murder that began the action of Richard II when Henry and Thomas Mowbray fell out over Richard's responsibility for the Duke of Gloucester's death. The killing of Richard not only slanders Henry, says the king, but also the entire country ('all this famous Land') because it earns England the reputation as a place of savagery. The RSC edition of Richard II, however, obscures all of this because it follows the 1623 Folio instead of the 1597 edition for the above lines, rendering them as:

BULLINGBROOK Exton, I thank thee not, for thou hast wrought

A deed of slaughter with thy fatal hand

Upon my head and all this famous land. ${ }^{37}$

The idea that a deed of slaughter (instead of slander) could apply to the whole of England is barely meaningful. Moreover, Henry has shown no compunction about slaughtering his enemies, and indeed as his public support grew he openly vowed this intention towards 'The caterpillars of the commonwealth', meaning Richard's favourites Bushy, Bagot and Green, 'Which I have sworn to weed and pluck away' (Richard II, 2.3.165-66). Bushy and Bagot were duly dispatched by Henry at Bristol after a brief show trial at which Henry explicitly declared that for their slaughter he should incur no public displeasure: 'to wash your blood/ From off my hands, here in the view of men/I will unfold some causes of your deaths' (Richard II, 3.1.5-7). Considered in this context of intense concern for public reputations, it is then virtually impossible that Henry should call Exton's killing of Richard a deed of slaughter rather than a deed of slander. The RSC Complete Works is forced to corrupt Shakespeare's meaning here - and in many hundreds of similar cases across the canon - because of a dogmatic adherence to the 1623 Folio as the basis for every play it contains, even where its textual corruption in transmission clearly takes us further from what Shakespeare wrote.

One further example will show how large an impact this dogma has upon the way readers apprehend Shakespeare's dramatic creations. In the sequel to Richard II, Shakespeare introduced his comic creation of fat Sir John, originally surnamed Oldcastle, but renamed shortly after the first performances as Falstaff. ${ }^{38}$ This sequel ended up being two plays, Henry IV, Parts I and II, in which Sir John displays at length his self-indulgence, cowardice and foul language. At least, he does if editors base their modern texts on the early editions printed shortly after these 
plays premiered in the 1590s. But for Henry IV, Part II the 1623 Folio publishers appear to have used a theatrical manuscript of the play that reflected expurgations made to bring it in line with a law passed in May 1606 called the 'Act to Restrain Abuses of Players'. The law prohibited the use of the name of God, Jesus Christ, the Holy Ghost or the Trinity of all three in any stage play.

Sir John's dialogue was written 8-10 years before this censorship law was passed and is full of swear-words that fall foul of such a prohibition, including oaths such as 'sblood (from 'God's blood') and swounds (from 'God's wounds'). This visceral language is a considerable part of the pleasure and interest of this character, and it appears unexpurgated in the first edition of the play, published in 1600. But in the manuscript used to print the 1623 Folio someone had softened Sir John's idiolect. Instead of answering the Lord Chief Justice's 'Well, God send the prince a better companion' with a witty 'God send the companion a better prince', ${ }^{39}$ the RSC Complete Works follows the Folio to give 'Well, heaven send the prince a better companion!' and 'Heaven send the companion a better prince!'.$^{40}$ The joke is intact, but weakened by the expurgation.

Instead of Sir John saying of the conscript Peter Bullcalf 'Fore God a likely fellow' ${ }^{41}$ he says, in the RSC Complete Works, "Trust me, a likely Fellow!'. ${ }^{42}$ Instead of taking his leave with a characteristically vigorous 'God keep you M. Scilens', Sir John in the RSC Shakespeare edition offers only a limp 'Farewell, Master Silence', and in response to Shallow's promise to come to court Sir John's 'Fore God would you would' becomes 'I would you would, Master Shallow'. ${ }^{43}$ Instead of swearing 'by the Lord', ${ }^{44}$ Sir John simply says 'I swear'. ${ }^{45}$ And his crucial welcoming cries to the new king Henry V are changed from 'God saue thy grace King Hall' and 'God saue thee, my sweet boy' to 'Save thy Grace, King Hal' and 'Save thee, my sweet boy!'. ${ }^{46}$ The ending of Henry IV, Part II depends on Sir John remaining the unregenerate figure we met in Henry IV, Part I and believing, vainly, that the world has finally turned his way because Prince Hal will remain unregenerate as king. By depriving Sir John of the full vigour of his language the RSC Complete Works gives the impression, quite unintended by Shakespeare, of a man who no longer speaks as forcefully as he did in Henry IV, Part I, as if he were reforming in anticipation of the new reign. Its only reason for doing this is an entirely unreasonable devotion to the Folio text, even where, as here, it is manifestly inferior. ${ }^{47}$

\section{The Norton Shakespeare third edition (2015)}

The second edition of The Norton Shakespeare (2008) essentially reprinted the first. For its third edition, The Norton Shakespeare broke from the 
Oxford Complete Works of 1986 and re-edited all the works afresh from the original documents. The primary editorial principle was 'single-text editing - that is, where more than one early authoritative text of a given play has survived, rather than merging them into one (as has traditionally been done), we have edited each text in its own right' ${ }^{\prime}{ }^{48}$ The point of doing this was not to represent the plays as first performed - the goal of the 1986 Oxford Shakespeare - but rather to render them 'as close as possible to the original versions read by Shakespeare's contemporaries' ${ }^{49}$ This readerly rather than theatrical Shakespeare addressed at once two of the main changes in editorial thinking since the 1980s: we no longer believe that we can see beyond the early editions to their antecedent underlying manuscripts and the mainly performative purposes for which they were created, and we now think that Shakespeare himself was interested in how his plays were read by his contemporaries.

The Norton's approach to authorial revision changed too, so that instead of a conflated King Lear this edition applied to that play the solution used for Hamlet in the preceding Norton editions: the 1623 Folio text was made primary and the lines found only in the 1608 edition were grafted into it but with typographical distinctions so that the reader who wished to could skip over them. As should be clear from the above discussion, this does not quite solve the problem of alterations where Shakespeare removed one piece of writing from the play and added something elsewhere in compensation for it, for which only a two-text solution is satisfactory. For Hamlet itself this 'scars-and-stitches' typographical approach was again used, but instead of making the 1623 Folio the base text and grafting into it the passages it lacks that appeared in the 1604-05 edition, The Norton Shakespeare now made the 1604-05 edition basic and grafted into it the passages found only in the Folio. Again, the weaknesses of such a procedure described above significantly impact upon the reader's experience of the play.

The most conspicuous matter on which the Norton third edition did not reflect the impact of recent thinking is Shakespeare's collaborative writing. The prefatory essay by Greenblatt mentioned collaboration in 'the late plays Pericles, Henry VIII, The Two Noble Kinsmen, the lost Cardenio, and - more debatably - such works as Henry VI, Part I, Titus Andronicus, and Timon of Athens', ${ }^{50}$ but this is only a partial list. Each of these allegedly debatable cases is in fact attested by multiple independent studies that put the case for co-authorship beyond dispute, and the Norton simply ignored the growing evidence of the co-authorship of Henry VI, Parts II and III and the clear evidence for Shakespeare's hand in Arden of Faversham and the revised Spanish Tragedy (see again the essay 
cited in footnote 9); those last two plays were simply left out of The Norton Shakespeare. The 'General Textual Introduction' to the edition mentioned Shakespeare's practice of co-authorship just once and only to liken it to the work of editing - risking the charge of self-aggrandisement and the Table of Contents gave no indication that many of the plays are not by Shakespeare but by Shakespeare and one or more others. ${ }^{51}$ The individual introductions to the plays frequently made no mention that what follows is not simply Shakespeare but, for whole stretches of many plays, someone else's writing. For Titus Andronicus, the Textual Introduction itself - where these matters are discussed for other plays made no mention of the hundreds of lines of Peele's writing in it.

\section{Conclusion}

Editors' views on how to turn the surviving documents that contain Shakespeare's works into readable modern editions change over time. Modern editions from the major publishers reflect these changing ideas and are themselves periodically rethought, making a Complete Works of Shakespeare purchased now significantly different from one purchased 50 years ago and highly different from one purchased 100 years ago. The most readily apparent difference over the past 50 years has been the universal acceptance of thorough-going modernisation of spelling in place of the incomplete modernisation practised before Wells's small book Modernizing Shakespeare's Spelling convinced virtually everybody of its necessity. ${ }^{52}$

Other changes in the intellectual bases of editing take longer to have an impact on what readers receive, but in general there is distinct evidence of steady progress: theory leads practice, and once a new idea - such as Shakespeare being essentially a man of the theatre, or being also a literary author, or being inclined to revise his plays - takes hold amongst scholars the major editions of his works begin to reflect this new thinking. There are, of course, moments of regression, and the RSC Complete Works, based on the Folio, is a signal example of an incoherent editorial policy producing an incoherent edition. We might lament that some ideas take longer to affect editorial practice than they should, the obvious example here being the well-attested case for Shakespeare's extensive co-authorship, but even conservative editions cannot hold back the rising tide of evidence on this topic. The impact of these matters on what readers read goes beyond the choice of words on the page, since - contrary to literary theories dominant since the 1960 s - authorship really does matter. Once we re-attribute a work, or part of it, we have changed the conditions and 
contexts in which it must be read. We are only just starting to make sense of the impact of these changes in the case of Shakespeare.

\section{Notes}

1. William Shakespeare (1623) Comedies, Histories and Tragedies, STC 22273 (F1) (London: Isaac and William Jaggard for Edward Blount, John Smethwick, Isaac Jaggard and William Aspley), sig. kk5v.

2. See Simon Palfrey and Tiffany Stern (2007) Shakespeare in Parts (Oxford: Oxford University Press).

3. William Shakespeare (1599) [Romeo and Juliet] The Most Excellent and Lamentable Tragedie, of Romeo and Juliet, STC 22323 BEPD 143b (Q2) (London: Thomas Creede for Cuthbert Burby), sig. B4r-C1r.

4. R. B. McKerrow (1935) 'A Suggestion Regarding Shakespeare's Manuscripts', Review of English Studies, 11: 459-65.

5. Gabriel Egan (2010) The Struggle for Shakespeare's Text: Twentieth-century Editorial Theory and Practice (Cambridge: Cambridge University Press), pp. 12-99.

6. William Shakespeare (1985) Hamlet, ed. Philip Edwards, The New Cambridge Shakespeare (Cambridge: Cambridge University Press), p. 32.

7. See William Shakespeare (1986) The Complete Works, ed. Stanley Wells, Gary Taylor, John Jowett, and William Montgomery (Oxford: Oxford University Press); Stanley Wells, Gary Taylor, John Jowett and William Montgomery (1987) William Shakespeare: A Textual Companion (Oxford: Oxford University Press).

8. See Paul Werstine (2013) Early Modern Playhouse Manuscripts and the Editing of Shakespeare (Cambridge: Cambridge University Press).

9. See Gary Taylor (2014) 'Why Did Shakespeare Collaborate', Shakespeare Survey, 67: 1-17.

10. See Lukas Erne (2003) Shakespeare as Literary Dramatist (Cambridge: Cambridge University Press); Lukas Erne (2013) Shakespeare and the Book Trade (Cambridge: Cambridge University Press).

11. A[lfred] Hart (1932) 'The Time Allotted for Representation of Elizabethan and Jacobean Plays', Review of English Studies, 8: 395-413; A[lfred] Hart (1932) 'The Length of Elizabethan and Jacobean Plays', Review of English Studies, 8: 139-54.

12. William Shakespeare (2006) As You Like It, ed. Juliet Dusinberre, The Arden Shakespeare (London: Thomson Learning), pp. 113-20.

13. The essay cited in note 9 above contains a full set of references of all the recent scholarship underpinning the new attributions.

14. Suzanne Gossett (2006) 'Editing Collaborative Drama', Shakespeare Survey, 59: 213-24.

15. Thomas Middleton (2007) The Collected Works, ed. Gary Taylor and John Lavagnino (Oxford: Clarendon Press), pp. 1165-201, 1542-85.

16. Gary Taylor and John Lavagnino (eds) (2007) Thomas Middleton and Early Modern Textual Culture: A Companion to the Collected Works (Oxford: Clarendon Press), p. 692.

17. Andrew Murphy (2003) Shakespeare in Print: A History and Chronology of Shakespeare Publishing (Cambridge: Cambridge University Press), pp. 221-29, 247-60. 
18. See Wells et al., William Shakespeare: A Textual Companion.

19. Stanley Wells and Gary Taylor (1990) 'The Oxford Shakespeare Re-Viewed', Analytical and Enumerative Bibliography, 4: 8-14.

20. William Shakespeare (1997) The Norton Shakespeare Based on the Oxford Shakespeare, ed. Stephen Greenblatt, Walter Cohen, Jean E. Howard, and Katharine Eisaman Maus (New York: W. W. Norton), p. xi.

21. Shakespeare, The Norton Shakespeare, pp. xii-xiii.

22. William Shakespeare (1997) King Lear, ed. R. A. Foakes, The Arden Shakespeare (Walton-on-Thames: Thomas Nelson), 1.1.69.

23. Stanley Wells (1988) 'The Unstable Image of Shakespeare's Text' in Werner Habicht, D. J. Palmer and Roger Pringle (eds) Images of Shakespeare: Proceedings of the Third Congress of the International Shakespeare Association in Berlin, 1-6 April 1986 (Newark DE: University of Delaware Press), p. 312.

24. Shakespeare, The Norton Shakespeare, p. xii.

25. Paul Werstine (1988) 'The Textual Mystery of Hamlet', Shakespeare Quarterly, 39: 3-4.

26. Shakespeare, Hamlet in The Norton Shakespeare, 5.2.146.11-12.

27. Shakespeare, Hamlet in The Norton Shakespeare, 5.2.76-79.

28. Shakespeare, The Norton Shakespeare, p. xiii.

29. Wells \& Taylor, 'The Oxford Shakespeare Re-viewed', 15.

30. Shakespeare, The Norton Shakespeare, p. 75.

31. William Shakespeare (1863) The Works, ed. William George Clark and John Glover, vol. 1: The Tempest, The Two Gentlemen of Verona, The Merry Wives of Windsor, Measure for Measure, The Comedy of Errors, 9 vols (Cambridge: Macmillan), pp. xxv-xxvi; Wells et al., William Shakespeare: A Textual Companion.

32. Gabriel Egan (forthcoming) 'Folio Provenance', in Emma Smith (ed.) The Cambridge Companion to Shakespeare's First Folio (1623) (Cambridge: Cambridge University Press).

33. John Jowett and Gary Taylor (1985) 'Sprinklings of Authority: The Folio Text of Richard II', Studies in Bibliography, 38: 151-200.

34. Shakespeare, Comedies, Histories and Tragedies, sig. ee4r-ee4v.

35. Jowett \& Taylor, 'Sprinklings of Authority: The Folio Text of Richard II'; Wells et al., William Shakespeare: A Textual Companion, pp. 306-307.

36. William Shakespeare (1597) [Richard II] The Tragedie of King Richard the Second, STC 22307 BEPD 141a (Q1) (London: Valentine Simmes for Andrew Wise), sig. K1v-K2r.

37. William Shakespeare (2007) Richard II in The Complete Works (=The Royal Shakespeare Company Complete Works), ed. Jonathan Bate and Eric Rasmussen (Basingstoke: Macmillan), 5.6.34-36.

38. Gary Taylor (1985) 'The Fortunes of Oldcastle', Shakespeare Survey, 38: 85-100; David Scott Kastan (1998), 'Killed with Hard Opinions: Oldcastle, Falstaff, and the Reformed Text of 1 Henry $I V$ ', in Laurie E. Maguire and Thomas L. Berger (eds) Textual Formations and Reformations (Newark DE: University of Delaware Press), pp. 211-27.

39. William Shakespeare (1600) [Henry IV, Part II] The Second Part of Henrie the Fourth, STC 22288 BEPD 167a(i) (Q) (London: V[alentine] S[immes] for Andrew Wise and William Aspley), sig. B3v.

40. Shakespeare, Henry IV, Part II in The Complete Works (=The Royal Shakespeare Company Complete Works), 1.2.141-42. 
41. Shakespeare, [Henry IV, Part II] The Second Part of Henrie the Fourth, sig. F1v.

42. Shakespeare, Henry IV, Part II in The Complete Works (=The Royal Shakespeare Company Complete Works), 3.2.129.

43. Shakespeare, [Henry IV, Part II] The Second Part of Henrie the Fourth, F3r; Shakespeare, Henry IV, Part II in The Complete Works (=The Royal Shakespeare Company Complete Works), 3.2.208, 14.

44. Shakespeare, [Henry IV, Part II] The Second Part of Henrie the Fourth, sig. G4v.

45. Shakespeare, Henry IV, Part II in The Complete Works (=The Royal Shakespeare Company Complete Works), 4.1.395.

46. Shakespeare, [Henry IV, Part II] The Second Part of Henrie the Fourth, sig. K4v; Shakespeare, Henry IV, Part II, in The Complete Works (=The Royal Shakespeare Company Complete Works), 5.5.35, 37.

47. For a while after its publication in 2007 the RSC Shakespeare Complete Works was used by the acting company to provide the scripts for its productions. The author was fortunate to witness a performance in which this Foliocentricity had significant unintended consequences. David Warner, who usually played Sir John in Michael Boyd's Henry IV, Part II of 2007-8, was one evening indisposed and so was his understudy. A series of role exchanges left Julius D'Silva (normally Bardolph) essaying the fat knight, a role for which he was unprepared and would need to read from a book. Rather than the unwieldy RSC Complete Works, D'Silva was given a small single-play edition, which from the Courtyard Theatre's first gallery could just be made out to be the Arden 2 edition by A. R. Humphreys, based on the 1600 edition. From Sir John's first scene it was clear that no one in the company had anticipated that Humphreys' edition would make Sir John say things that the rest of the cast were not expecting. The cast were hearing and visibly responding to a Sir John who was not only unaccountably restored to the rhetorical vigour they had not witnessed since Part One, but who was also giving cues they were not expecting and expecting cues they had not practised to give. D'Silva earned a standing ovation for overcoming formidable difficulties in his performance, a great many of which no one on stage had anticipated.

48. William Shakespeare (2015) The Norton Shakespeare, Third edition, ed. Stephen Greenblatt, Walter Cohen, Suzanne Gossett, Jean E. Howard, Katharine Eisaman Maus and Gordon McMullan (New York: W. W. Norton), p. xxv.

49. Shakespeare, The Norton Shakespeare, Third edition, p. xxv.

50. Shakespeare, The Norton Shakespeare, Third edition, p. xxvii.

51. Shakespeare, The Norton Shakespeare, Third edition, p. 91.

52. Stanley Wells and Gary Taylor (1979) Modernizing Shakespeare's Spelling, with Three Studies in the Text of Henry V (Oxford: Clarendon Press).

\section{Select Bibliography}

Egan, Gabriel (forthcoming) 'Folio Provenance' in Emma Smith (ed.) The Cambridge Companion to Shakespeare's First Folio (1623) (Cambridge: Cambridge University Press).

Egan, Gabriel (2010) The Struggle for Shakespeare's Text: Twentieth-Century Editorial Theory and Practice (Cambridge: Cambridge University Press). 


\section{Gabriel Egan}

Erne, Lukas (2013) Shakespeare and the Book Trade (Cambridge: Cambridge University Press).

Erne, Lukas (2003) Shakespeare as Literary Dramatist (Cambridge: Cambridge University Press).

Wells, Stanley and Gary Taylor (1979) Modernizing Shakespeare's Spelling, with Three Studies in the Text of Henry V (Oxford: Clarendon Press).

Wells, Stanley, Gary Taylor, John Jowett and William Montgomery (1987) William Shakespeare: A Textual Companion (Oxford: Oxford University Press).

Werstine, Paul (2013) Early Modern Playhouse Manuscripts and the Editing of Shakespeare (Cambridge: Cambridge University Press). 